\title{
New record of three species of Leeches (Annelida:Hirudinea) in Al-Hindyia River / Babil Province / Iraq
}

Nadia Imad AL-Ameen *

\author{
Haifa Jawad Jawair
}

Received 15/10/2018, Accepted 5/3/2019, Published 22/9/2019
(c) (i) This work is licensed under a Creative Commons Attribution 4.0 International License.

\begin{abstract}
:
In this study, a total of 209 individuals of leeches were collected from Al-Hindyia River / Babil Province. 116 individuals were identified as Erpobdella octaculata (Linnaeus, 1758), 50 individuals as Erpobdella punctata (Leidy,1870) and 43 individuals as Hemiclepsis marginata (Müller, 1774). Four samples were collected monthly during a period from February to June 2018. Some physical and chemical water properties were also examined, including air and water temperature, potential of hydrogen $\mathrm{pH}$, Electrical Conductivity EC, Total Dissolved Solid TDS, Dissolved Oxygen DO, and the Biological Oxygen Demand $\mathrm{BOD}_{5}$. Air and water temperature were ranged $19.5-29, \& 14.6-23.2{ }^{\circ} \mathrm{C}$ respectively. The values of $\mathrm{pH}$ ranged 6.2-7.6. EC ranged 1104-1581 $\mu \mathrm{s} / \mathrm{cm}^{2}$. The TDS recorded 669- $767 \mathrm{mg} / \mathrm{l}$, while the DO reached $1.3-8.5 \mathrm{mg} / 1$, the $\mathrm{BOD}_{5}$ ranged $3.5-5.7 \mathrm{mg} / \mathrm{l}$.
\end{abstract}

Key words: Erpobdella ,Hemiclepsis ,Hirudinea, Leeches.

\section{Introduction:}

Al-Hindyia River is considered as one of the main branch of Euphrates River after AlHindyia dam. It passes through Karbala and Babylon Provinces to wide spaces of farm lands and palm trees orchards in Al-Kifil region / Babil province. About five kilometer after Al-Kifil city the river branches, to AL-Kufa river and ALAbasya river (Fig. 1). The waters source of these two rivers is what stored of waters in reservoirs or from rain $(1,2)$.

Leech species are classified as phylum Annelida, class Clitellata, sub class Hirudinea. They are common benthic invertebrates with a worldwide distribution. Their distribution and diversity are affected directly by the ecological circumstances, physiochemical factors, and interferences food relationships among the benthic community such as predation, competition and parasitism in the water or the ecosystem where they are found (3).

The body of leech is divided into segments and surrounded by a thin flexible cuticle. They have oral sucker and posterior ventral sucker at the end of the body which makes leeches different from other annelids. They are hermaphrodite, reproduced by the cross- fertilization and lay their fertilizing eggs in cocoon secrete by the clitellum. Most leeches are free living animals, feed on the small Department of Biology, College of Science for Women, University of Baghdad, Baghdad, Iraq.

"Corresponding author: nadiaimadalameen@gmail.com invertebrates, while some are parasites, feed on the blood or body fluids of the aquatic vertebrates (3).

According to $(4,5)$ freshwater leeches are divided into 3 orders:

1. Order Rhynchobdellida:. Mouth is a small pore on the head sucker through which, the pharyngeal proboscis may be protruded to feed on the blood or body fluid of the prey. There are no jaws or denticles. Blood is colorless. They have no penis, and sperm are exchanged by inserting sperm sacs into the wall of the body of the partner in an unknown way. All are parasites or predators in aquatic habitats. This order includes species of family Glossiphoniidae, and family Piscicolidae.

2- Order Gnathobdellida: Pharynx is a section bulb, not extending to clitellum ; eyes 5 pairs in an arch on II-VI; somite have 5-annulates ; muscular jaws present, testisacs large and testes arranged in metameric pairs, mostly 10 , this order includes species of family Hirudinidae,

3- Order Pharyngobdellida : pharynx is a crushing tube extending to XIII, eyes 3-4 pairs in separate labial and buccal groups; somite 5-annulate, but often further divided; Individuals have three muscular pharyngeal ridges but no true jaws or denticles. Testisac very small and numerous, arranged in grape-branch pattern. This order includes species of family Erpobdellidae

Most information on the leeches in Iraq was concerned with fish parasitic species. Piscicola sp. 
was recorded by (6) collected from Barbus schejch in different regions of Iraq, while Hemiclepsis margunata recorded in Barbus sharpeyi. From Tigris River, Mosul city; Cystibranchus mastacembeli was collected from freshwater spinyback fish Mastacembelus simach (7); Piscicola geometrawas from Aspiusvorax collected from Euphrates River at Al-Anbar province (8), and Cystibranchus mammillatus from Mastacembelus mastacembelus collected from Greater Zab River in Kurdistan region (9).

About free living species, specimens were collected from Greater Zab, river and identified as Fadejewobdella quinqueannulata (10), and Dina lineata (11), while Dina punctata was recorded in Al-Swaib marshes, Basra province (12), and in the north of Iraq from the Lesser Zab (13). From Tigris River within Baghdad City, Glossiphonia heteroclita and Glossiphonia complanata were collected from aquatic plants by $(14,15)$ respectively.

The aim of this study is to identify leech specimens, collected within the benthic invertebrates sampled from Al-Hindya River at ALKifil city, and study their ecological prevailing factors .

\section{Materials and Methods:}

Four benthic samples of aquatic plants were collected monthly from AL-Hindyia River, Al-Kifil region ( $32^{\circ} 13^{\prime} 26.15^{\prime \prime} \mathrm{N}, 44^{\circ} 21^{\prime} 46.40^{\prime \prime} \mathrm{E}$ ) ( Fig 1), during the period from February to June 2018 by a hand shovel, $1 \mathrm{~m}$ from the river edge. Each sample was taken by three times as replicates. The samples were collected in a suitable size plastic container filled with fresh water from the river, and transported to the laboratory, where the reserved in a glass aquarium $(40 \times 25 \times 29)$. Few days later the leeches were inspected within the aquarium sediment, and separated in a special container for microscopic examination. The species were examined for identification using 6,4X objective lens of dissecting microscope (WILD M38), and identified according to (5), (16) and (17). Some ecological measurements were conducted directly in the study site, such as air and water temperature using mercuric thermometer, while $\mathrm{pH}$ and $\mathrm{EC}$ $\mu \mathrm{s} / \mathrm{cm}^{2}$ were measured by (HACH HQD) multimeter device, TDS was measured by using digital portable multi-meter (WTW340i). DO \& $\mathrm{BOD}_{5}$ were measured by winkler modified method according to (18).

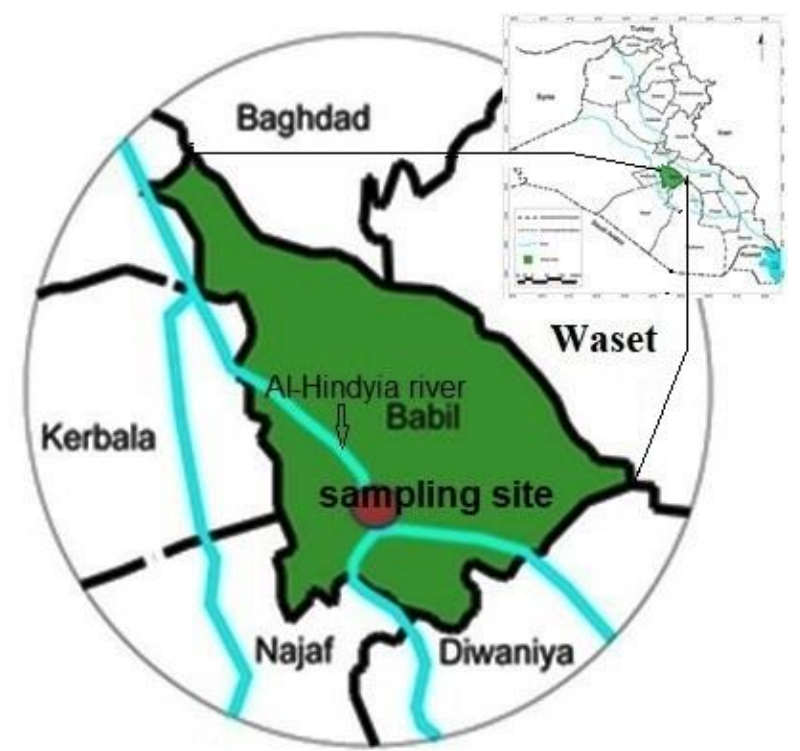

Figure1. Map showing the sampling site

\section{Results and Discussion:}

Table (1) illustrates the values of the ecological measurements of the river water during the samples collecting period. Air and water temperature values ranged between $19.5-29, \&$ $14.6-23.2^{\circ} \mathrm{C}$ respectively, whereby the least degree was recorded in February and the highest in April; $\mathrm{pH}$ values were ranged between 6.2-7.6, while Ec. values was about $1104-1581 \mu \mathrm{s} / \mathrm{cm}^{2}$. The values of TDS were 669-767 mg/l.; DO were 1.3-8.5 mg/l., and the $\mathrm{BOD}_{5}$ were $3.5-5.7 \mathrm{mg} / \mathrm{l}$. Algal blooming was observed in April because of Eutrophication and water level reduction due to low water supply in this month resulting in negative ecological results, that is why there were high values in EC, TDS and $\mathrm{BOD}_{5}$, while there was the lowest value of DO was recorded, because of the algal death, molt and bacterial decomposition (19).

Table 1. Range and average values of environmental factors prevailing in Al-Hindyia river during the study period (Feb-May, 2018)

\begin{tabular}{ccc}
\hline Ecological factors & Range & Average \\
\hline Air temperature & $(19.5-29)$ & 23.1 \\
Water temperature & $(14.6-23.2)$ & 18.9 \\
$\mathrm{pH}$ & $(6.2-7.6)$ & 6.7 \\
Electrical conductivity EC & $(1104-$ & 1293.7 \\
$\mu \mathrm{s} / \mathrm{cm}^{2}$ & $1581)$ & \\
Total dissolved suspended TDS & $(669-767)$ & 696.5 \\
$\mathrm{mg} / \mathrm{l}$ & 6.3 \\
$\begin{array}{c}\text { Dissolved oxygen DO mg/l } \\
\text { Biological oxygen demand } \\
\text { BOD }_{5} \mathrm{mg} / \mathrm{l}\end{array}$ & $(1.3-8.5)$ & $6.5-5.7)$ \\
\hline
\end{tabular}

A total of 209 individuals of leeches were collected during the study period (Table2). They were identified to three species: Erobdella octoculata (Linnaeus, 1758), comprise $55 \%$ of the 
total number; Erpobdella punctata (Leidy,1870) comprise 24\%, and Hemiclepsis marginata (Müller1774), which comprise $21 \%$ of the total number of collected leeches ( Fig. 2).

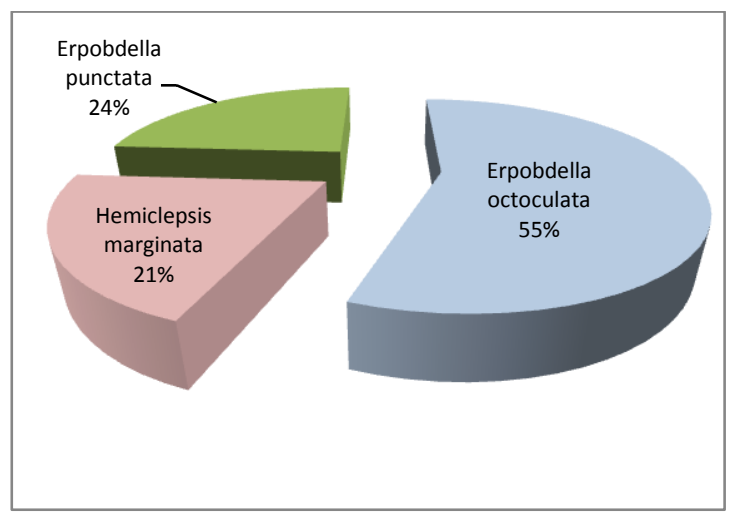

Figure 2. Percentage of the individual number of each species of leech within the total number of identified Leeches

Two species of the genus Erpobdella were found in this study, belonging to the order Pharyngobdella , family Eropobdellidae, they were:

Erpobdella octoculata, which has four pairs of eyes arranged in the form of two pair in the middle, a pair on each side of the head in the anterior part of the body, dorsal surface marked with black pigment varying from dense reticulum to a few scattered flecks (Fig.3). Genital pore separated by 2-3 annuli, coulor reddish- brown or dark brown, length at rest $3-4 \mathrm{~cm}$.

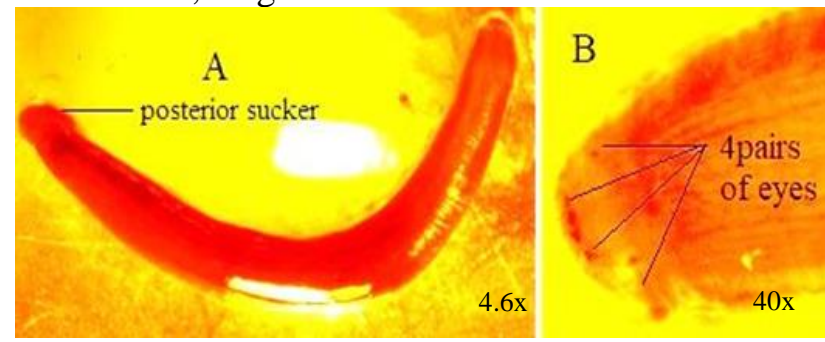

Figure 3. Erpobdella octoculata A- whole mount; $B$ - anterior end showing the eye position

Erpobdella punctata, has three pairs of eyes, $1^{\text {st }}$. pair labial, and found on somite II, and two buccal pairs. Several color phase,, ranging from oily to dark green but mostly with 2 or 4 broad longitudinal stripes of brown spotted with ashy grey (Fig.4). Gonopore separated by 2 annuli. This species was recorded in Al-Swaib marshes, Basra province as Dina punctata (12).

Species of genus Erpobdella have 5annulated somite, being equal in length, gonophores separated by 3 annuli (17). The family Erpobdellidae has a worldwide distribution, with about 60 species, all occur in freshwater but some are amphibious. They return to fresh water in the breeding season and their cocoons are attached to the substratum. All species are carnivorous and their invertebrate prey is usually swallowed as a whole (16).

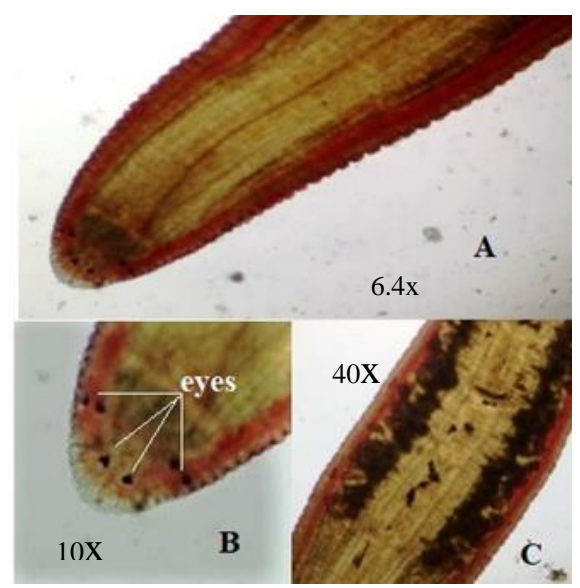

Figure 4. Erpobdella punctate, $\mathrm{A}$-anterior portion of the body; B- anterior end show the position of the eyes; $\mathrm{C}$ middle portion of the body showing the brown spotted stripes

The third identified species was Hemiclepsis marginata belonging to the order Rhynchobdella, family Glossiphoniidae. The head and the posterior sucker during relax status are wider than the next direct segments, two pairs of eyes in the third and fifth segments of the body; the first and second pair of eyes are frequently diffused, the proboscis is found. The body color is green, yellow or pale brown with seven rows or aggregation of yellow pigments (Fig 5). The body length is $1.6-1.8 \mathrm{~cm}$. It was recorded in Europe, and Asia which is widespread in Siberia. It is considered as a scavenger, but when it starves, it attacks small fish. The cocoons are held by a gelatin material on the ventral side of the body of the parent, then after three weeks they will be hatched. One adult can hold an average of 12-125 cocoons. The individual carrying the young is characterized by a crooked movement especially in the anterior portion of the body or roll from part to part, this phenomenon was also described by (16). This species was noted by (20) in a pond near Baghdad in 1985 received its water from the Tigris River. 


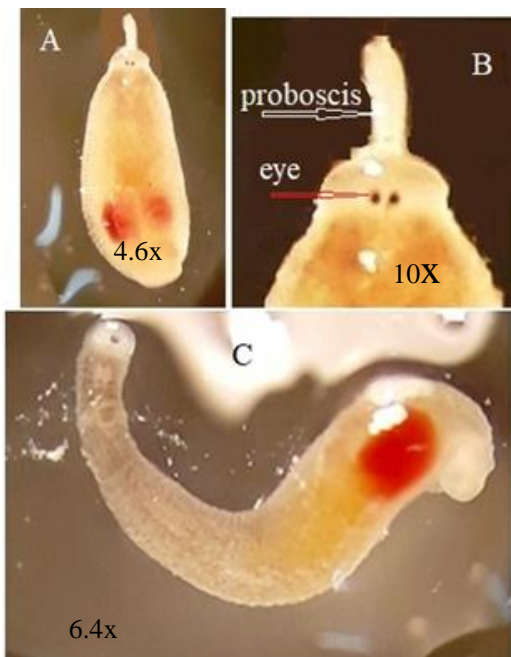

Figure 5. Hemiclepsis marginat A-Whole mount; B- anterior end; C- a crooked movement

In Iraq some species of family Erpobdellidae were recorded as Dina lineata (11) and D. puntata (13), while (16) indicated that some authors regarded the genus Dina as only subgenus of genus Erpobdella. The author also referred to Herpobdella as a synonyme of Erpobdella. E.octuculata existence was previously recorded in som laks and sprigs in Erbil, Sulymania and Dahuk / North of Iraq in Irbil by (21).
It was noted from Table (2) that E. octoculata recorded the highest individual numbers (116 individuals), that refer to sits availability and appropriateness of the ecology for its growth, also the adult individuals have the ability for leaving water at night and go up to the nearby wet or terrestrial land searching for food (16). This species is highly resistant for the ecological changes and has the ability to stay in organic pollution and Eutrophic habitat $(22,23)$. This species was considered by (24) as predator for Chironomus larvae, Trichoptera, Oligochaeta, Coppoda, Ostracoda, and Cladocera, and this depends on the size of the leech body. Fortunately, all of these invertebrates groups were dominant in the study site. The adults can also eat the young of other leeches or the recent hatched cocoons that are not their babies. It has been found that each adult can eat more than three chironomid larvae during one night .The highest weight of this species reaches $667 \mathrm{mg}$. The individuals reach to maturity during one year if there abundance of chironomid larvae , Oligochaetes worm Tubifex, and temperature range $10-15^{\circ} \mathrm{C}$, but they will die just after the first breeding (16).

Table 2. Individuals number of different Leeches species collected from Al-Hindyia river during the period (Feb.-May 2018)

\begin{tabular}{cccccc}
\hline Date of sample & Species & $\begin{array}{c}\text { Erpobdella } \\
\text { octoculata }\end{array}$ & $\begin{array}{c}\text { Hemiclepsis } \\
\text { marginata }\end{array}$ & $\begin{array}{c}\text { Erpobdella } \\
\text { punctata }\end{array}$ & Total \\
\hline Feb. & 28 & 7 & 16 & $\mathbf{5 1}$ \\
march & 18 & 11 & 20 & $\mathbf{4 9}$ \\
April & 41 & 6 & 4 & $\mathbf{5 1}$ \\
May & 29 & 19 & 10 & $\mathbf{5 8}$ \\
Total & $\mathbf{1 1 6}$ & $\mathbf{4 3}$ & $\mathbf{5 0}$ & $\mathbf{2 0 9}$
\end{tabular}

\section{Conclusions:}

The results revealed the three species of leeches, Erpobdella octaculata (Linnaeus, 1758), Erpobdella punctata (Leidy, 1870) and Hemiclepsis marginata (Müller, 1774) were previously recorded in Iraq, but they are considered as new record in Euphrates River.

\section{References:}

1.Azeez HK, Umran HA, MaithamKH. Water pollution in the stream of AL-Kifl Journal of Babylon University for basic education. 2015; (19):594-604.

2.Salman JM, Lafta SK, Jawad HJ.A limnological study on AL-Abasya River-Iraq Al- Qadisiyah Journal Of Pure Science. 2008(1)3:48-53.

3. Langer SV, Vezsenyi AK , Carle DD, Beresford DV, Kvist S. Leeches (Annelida: Hirudinea) from the far north of Ontario: distribution, diversity, and diagnostics Can. J. Zool . 2018; 96 (2): 141-152.
4. Pechenik JA. Biology of Invertebrates. $7^{\text {th }}$. Ed. McGraw -Hill Education. 2014. 590 p.

5. Edmondson WT. Freshwater Biology. $2^{\text {nd }}$. Ed. John Wiley \& Sons. INC. New York. 1959. 1248pp.

6. Kalifa KA. Leeches on freshwater farmed fishes in Iraq. J. Wild. Dis.1985; 21 (3): 312-313.

7. Rahemo ZI F. Cystibranchus mastacembeli (Annelida: Hirudinea) from the Iraqi freshwater spinyback, Mastacembelus simach (Wabaun, 1792). Riv. Parasitol. 1989 50(1) : 121-126.

8. Mhaisen FT, Al-Khateeb GH, Balasem AN, Mutar AJ. On a collection of some fish parasites from Euphrates River, Anbar province, Iraq. Babylon. Univ. J., Pure. Appl. Sci. 1997; 2(3): 267-272.

9. Bashê SKR. The parasitic fauna of spiny eel Mastacembelus mastacembelus (Banks and Solanser, 1794) from Greater Zab River-Kuristan regionIraq. Sci. Edu. Coll., Univ. Salahaddin Press;2008

10. Ali LA. First record of Fadejewobdella quinqueannulata (Hirudinea: Erpobdellidae) in 
Greater Zab River-Iraq. Zanco the Scie. J. of the Univ. of Salahaddin. 2007;2(22):47-50.

11. ALI LA, JAWAIR HJ. First Record of Dina Lineata (Hirudinea: Erpobdellidae) in Greater Zab River Kurdistan Region-Iraq. Science Journal of University of Zakho. 2013 Jun 30;1(1):207-9.

12. AL-Khzali AMG. Identification and biologicalstudy of the freshwater leech Dina punctate Johansson, 1927(Erpobdellidae:Hirodinea) in AL-Swaib Marshes from Basrah province south of Iraq.Edu. for pure sciences col. Basrah Univ.2016.107p.

13. Bilal S, Ali L, Abdullah LY, Khailany RA, Dhahir SF, Abdullah SM .First record of leech Dina punctata (Annelida: Erpobdellidae) from Lesser Zab River in northern Iraq: Morphological and molecular investigation. Jordan Journal of Biological Sciences.Jun.2017.10(2):69-72.

14. Jaweir HJ, Abid-Ali HH. Association of aquatic worms infected snail with Digenean larvae. Baghdad Sci. J. 2015. 12(2):273- 278.

15.Salman MD, Shebli MK, Alfalah MJO, Aenab AM.. Sorting of Glossiphonia complanata (Linnaeus, 1758) (Rhynchobdellida: Glossiphoniidae) from three aquatic plants in Tigris River within Baghdad city. Egypt. J. Petrol. 2017. 26 (3): 851-853.

16. Elliott JM, Mann KH. A key to the Freshwater Leeches With notes on their life cycle and ecology. Freshwater Biological Association Scientific Publication No.40; 199872pp.
17. Klemm DJ. Freshwater Leeches (Annelida: Hirudinea) of North America. Biota of freshwater Freshwater Ecosystems, Identification Manual No. 8. Environmental Protection agency. 1972. 53pp+ Viii.

18. American public Health Association ( APHA). Standard methods for examination of water and wastewater. $20^{\text {rd }}$ Ed. Washington DC, 2003.

19. Shinde R, Gawande S. Eutrophication and Aquatic Life. Int. J. Adv. Sci. Eng. Tech.2016; 4(2) : 238-243.

20.Khalifa KA, Leeches on freshwater farmed fishes in Iraq. Journal of wildlife disease .1985 Jul:21(3),312314.

21. Ahmed ST, Rahemo ZI. Reproductive Strategies In Freshwater Leech Erpobdella Octoculata (Euhirudinea; Acanthobdellida. International Science Journal.2014:1(1):70-74.

22. Kaygorodova IA. Annotated checklist of the leech species diversity in the Maloe More Strait of Lake Baikal, Russia. Zoo keys. 2015 . (545): 37-52.

23. Friberg N, Skriver J, Larsenm SE, Pedersen M L, Buffagni A. Stream macro-invertebrate occurrence along gradients in organic pollution and eutrophication. Freshwater Biology. 2010; 55(7): 1405-1419

24.Kazancei N, Ekingen P, Dugel M , Turkmen G. Hirudinea(Annelida)Species and their Ecological Preferences in Some Running Water and Lakes Int. J. Environ. Sci. Technol. 2015 12:1087-1096.

\section{تسجيل جديد لثلاث انواع من العلقيات (ديدان حلقية:السرجيات) في نهرالهندية / محافظة بابل/ العراق}

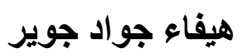

$$
\text { ناديا عماد طارق }
$$

قسم علوم الحياة، كلية العلوم للبنات، جامعة بغداد، بغداد، العراق.

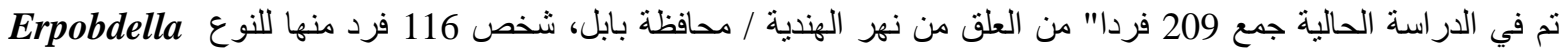

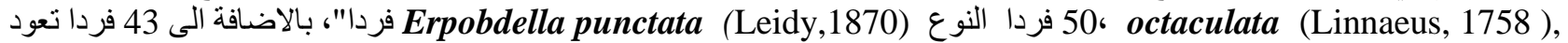

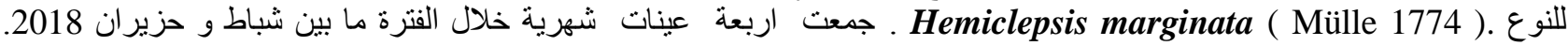

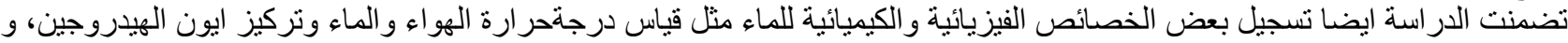

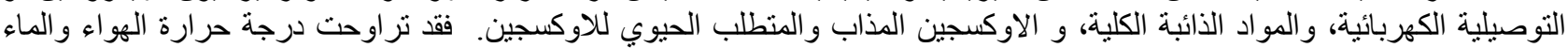

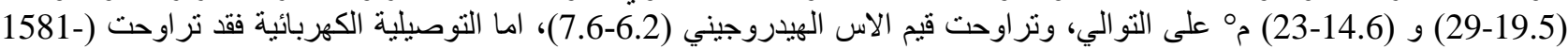

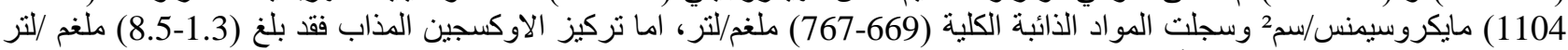
وتراوح تركيز المنطلب الحيوي للأوكسجين (3.5-5.7) ملغخ /لتر. 